\title{
FIRST RECORD ON MELANISM IN SEMNOPITHECUS PRIAM FROM TAMIL NADU, INDIA
}

\author{
Arockianathan Samson ${ }^{1, *}{ }^{*}$, Kamaldeen A. Hakkeem² ${ }^{2}$ Jabamalainathan L. Princy ${ }^{3}$ (D) \\ ${ }^{1}$ Bombay Natural History Society, India \\ ${ }^{2}$ Wildlife Nature and Conservation Trust, India \\ ${ }^{3}$ Government Arts College, India \\ *e-mail: kingvulture1786@gmail.com
}

Received: 01.10.2020. Revised: 10.12.2020. Accepted: 12.12.2020.

\begin{abstract}
Semnopithecus priam is a Near Threatened species found in southern India and Sri Lanka. On 25 July 2020, a melanistic S. priam individual was observed in Nilgiris, Tamil Nadu, India. This observation revealed that it is the first known case of melanism in Semnopithecus priam in India and its distributional range.
\end{abstract}

Key words: Cercopithecidae, mammal, Nilgiris, primate, Western Ghats

Melanism is a colour polymorphism common in various groups of organisms, in which the skin/ fur/plumage is darker than one considers as normal or «wild» phenotype. Semnopithecus priam Blyth, 1844 is a Near Threatened Old World monkey. It is widely spread in southern India, mainly on the eastern side of the Deccan plateau, Eastern Ghats, Western Ghats, east of the River Moyar, on the eastern slopes of the southern part of Western Ghats and the plains of Tamil Nadu (Chetan et al., 2014) and in Sri Lanka. In India, a colour aberration in mammals is comprehensively documented (Mahabal et al., 2019). However, in primates, it has been recorded only in Macaca assamensis McClelland, 1840, M. mulatta Zimmermann, 1780, and M. radiata É. Geoffroy, 1812. So, the present note represents the first known case of melanism in S. priam in Nilgiris, Western Ghats, Southern India.

On 25 July 2020 , at $16: 30 \mathrm{~h}$, during the birdwatching in Mulli areas $\left(76.73068^{\circ} \mathrm{N}, 11.21721^{\circ} \mathrm{E}\right)$ of the Nilgiris, Tamil Nadu, India, we observed a troop of $S$. priam. Within the troop, body and tailcoat colour of one of adult male individuals was completely darker (black), while its head was normally coloured like other individuals. Therefore, we concluded that the $S$. priam adult was affected melanism. Then, we photographed the individuals for further considering (Fig.).

Melanism can be defined as the excessive deposition of the pigment melanin resulting in an atypically dark individual (Kettlewell, 1973). Such colour aberration is quite common in mam- mals (Caro, 2005). The natural coat colour of the $S$. priam pelage is brownish to light-grey and silky in appearance. The ventrum is a creamyyellow in colour and the infants are black. The natal coat colour of one individual at adulthood was completely different (Menon, 2014). The tropical ecosystem supports the hypothesis that melanism can provide an adaptive advantage under certain ecological conditions (Caro, 2005; Allen et al., 2010). Moreover, there is the hypothesis of an association between darker individuals and wetter areas with dense vegetation (Gloger, 1833; Cott, 1940; Ortolani \& Caro, 1996; Ulmer, 1941). Habitat fragmentation, stress and inbreeding are possible elements for melanism occurrence (Tougias, 2011; Ramakrishnan et al., 2016). In this juncture, more observation is warranted to predict the reason behind this kind of melanism in $S$. priam in Nilgiris.

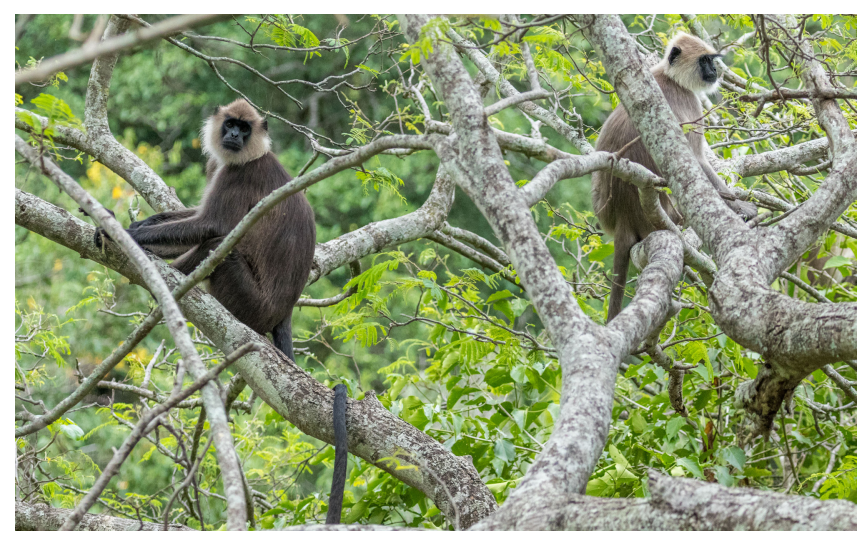

Fig. The melanistic Semnopithecus priam individual in Mulli, Nilgiris, Tamil Nadu, India. 
In conclusion, further studies must be encouraged to report the records of colour aberration in wildlife. This is necessary for a better understanding of this phenomenon and its insights into the ecological and physiological implications of this condition considerably affecting the animal survival (Samson et al., 2017).

\section{References}

Allen W.L., Cuthill I.C., Scott-Samuel N.E., Baddeley R. 2010. Why the leopard got its spots: Relating pattern development to ecology in felids. Proceedings of the Royal Society B: Biological Sciences 278(1710): 1373 1380. DOI: $10.1098 /$ rspb.2010.1734

Caro T. 2005. The adaptive significance of coloration in mammals. BioScience 55(2):125-136. DOI: 10.1641/0006-3568(2005)055[0125:TASOCI]2.0.CO;2

Chetan N., Praveen K.K., Vasudeva G.K. 2014. Delineating Ecological Boundaries of Hanuman Langur Species Complex in Peninsular India Using MaxEnt Modeling Approach. PLoS ONE 9(2): e87804. DOI: 10.1371/ journal.pone.0087804

Cott H.B. 1940. Adaptive Coloration in Mammals. London: Methuen. 508 p.

Gloger C.W.L. 1833. Das Abändern der Vögel durch Einfluss des Klimas: Nach zoologischen, zunächst von dem europäischen Landvälgeln, entnommenen Beobachtungen dargestellt, mit den entsprechenden Erfahrungen bei den europäischen Säugthieren verglichen, und durch Tatsachen aus dem Gebiete der Physiologie, der Physik und der physischen Geographie erläutert. Breslau: August Schulz \& Co. 159 p.

Kettlewell H.B.D. 1973. The evolution of melanism. Oxford: Clarendon Press. 388 p.

Mahabal A., Sharma R.M., Patil R.N., Jadhav S. 2019. Colour aberration in Indian mammals: a review from 1886 to 2017. Journal of Threatened Taxa 11(6): 1369013719. DOI: 10.11609/jott.3843.11.6.13690-13719

Menon V. 2014. Indian Mammals: A Field Guide. Gurgaon: Hachette India Local. 528 p.

Ortolani A., Caro T.M. 1996. The adaptive significance of color patterns in carnivores: phylogenetic tests of classic hypotheses. In J.L. Gittleman (Ed.): Carnivore behavior, ecology, and evolution. Vol. 2. Ithaca: Cornell University Press. P. 132-188.

Ramakrishnan B., Samson A., Ramasubramanian S. 2016. Observation of melanism in Indian Giant Flying Squirrel (Petaurista philippensis) at Sathyamangalam Tiger Reserve, Tamil Nadu, SouthernIndia. Zoo's Print 31(9): 8.

Samson A., Ramakrishnan B., Bargavi S. 2017. Leucism in the three-striped palm squirrel (Funambulus palmarum) at Gudalur Forest Division, Tamil Nadu, Southern India. Therya 8(3): 261-262. DOI: 10.12933/therya-17-503

Tougias R. 2011. The Quest For The Eastern Cougar: Extinction or Survival?. Bloomington: iUniverse Publishing. 336 p.

Ulmer F.A. 1941. Melanism in the Felidae, with special reference to the genus Lynx. Journal of Mammalogy 22(3): 285-288. DOI: $10.2307 / 1374954$

\title{
ПЕРВОЕ УКАЗАНИЕ МЕЛАНИЗМА ДЛЯ SEMNOPITHECUS PRIAM ИЗ ТАМИЛ НАДУ (ИНДИЯ)
}

\author{
А. Самсон, ${ }^{1, *} \mathbb{D}$, К. А. Хаккеем², Дж. Л. Принси ${ }^{3}$ \\ ${ }^{1}$ Общество естественной истории Бомбея, Индия \\ ${ }^{2}$ Фонд дикой природы и ее охраны, Индия \\ ${ }^{3}$ Правительственный колледж искусств, Индия \\ *e-mail: kingvulture1786@gmail.com
}

\begin{abstract}
Semnopithecus priam является видом, близком к угрожаемому состоянию на территории Южной Индии и Шри Ланки. Меланистическая особь S. priam была обнаружена в округе Нилгири (штат Тамил Наду, Индия) 25 июля 2020 г. Данное наблюдение показало, что это первый известный случай меланизма для $S$. priam как в Индии, так и в пределах всего ареала вида.
\end{abstract}

Ключевые слова: Cercopithecidae, Западные Гаты, млекопитающее, округ Нилгири, примат 